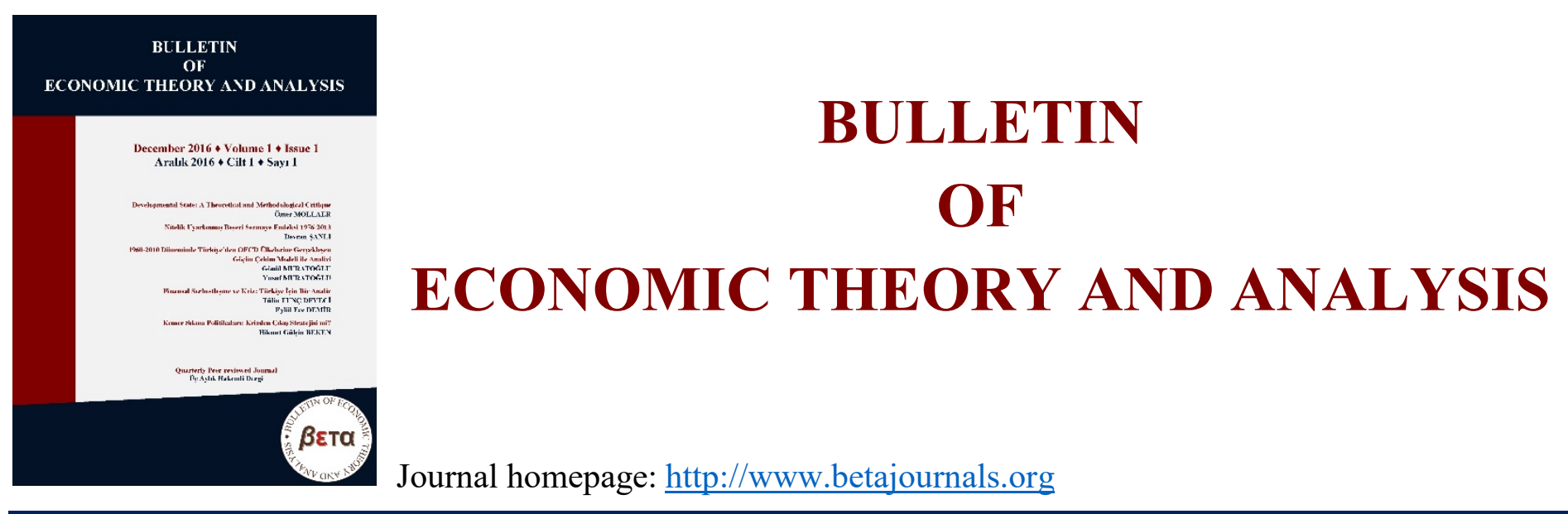

\title{
A Comparison of Working Capital Components of Turkish and Indian Cement Firms
}

\section{İlker SAKINÇ $\odot \underline{\text { https://orcid.org/0000-0002-9549-8563 }}$}

To cite this article: Sakınç, İ. (2018). A Comparison of Working Capital Components of Turkish and Indian Cement Firms. Bulletin of Economic Theory and Analysis, 3(4), 261-272.

Received: 25 Nov 2018

Accepted: 16 Dec 2018

Published online: 30 Dec 2018

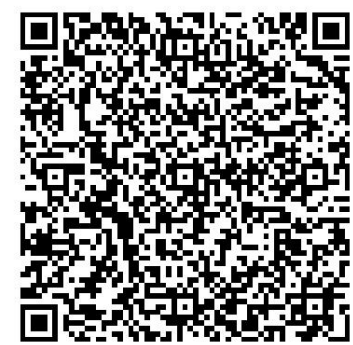

CAll right reserved 


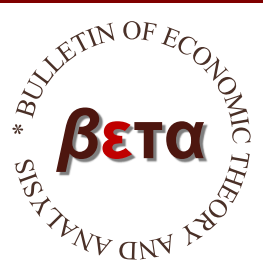

\title{
Bulletin of Economic Theory and Analysis
}

\author{
Volume III, Issue 4, pp. 261-272, 2018
}

http://www.betajournals.org

Received / Alınma: 25.11.2018 Accepted / Kabul: 16.12.2018

\section{A Comparison of Working Capital Components of Turkish and Indian Cement Firms}

\author{
İlker SAKINÇa \\ a Assoc. Prof. Ph.D., Hitit University, FEAS, Department of Banking and Finance, Corum, \\ TURKEY
}

\begin{abstract}
Working capital management is the management of current assets and current liabilities. It is the main issue for financial managers because there is a close relation between working capital management and profitability. The components of working capital determine the level of profitability and risk of the firm. This study analyzes the comparison of working capital components of two different countries. For this study, Turkish and Indian Cement Industries are selected. According to list of top countries by cement production in 2013 based on USGS Mineral Program Cement Report, India is the second and Turkey is the seventh largest producer of cement in the world. This study indicates the working capital management applications of two different countries. As working capital components, Average Inventory Days, Average Payables Days, Average Net Trade Cycle, Average Receivables Collection Periods, Cash and Equivalent/ Total Assets and Working Capital/ Sales are used. Return on Assets, Return on Equity and Net Profit Margin are used for profitability indicators. The independent ttest is used to compare the means of working capital components of Turkish and Indian Cement firms for a period of 2007-2014.
\end{abstract}

Anahtar Kelimeler Cement Industry, Working Capital, tTest

JEL Kodu G30, G31

CONTACT İlker SAKINÇ $\bowtie$ ilkersakinc@hitit.edu.tr $\risingdotseq$ Assoc. Prof. Ph.D., Hitit University, FEAS, Department of Banking and Finance, Corum, TURKEY (1) https://orcid.org/0000-0002-9549-8563

* This paper was presented in Annual Spain Business Research Conference 14 - 15 September 2015 , Novotel Barcelona City Hotel, Barcelona, Spain and it was published in the proceedings of the conference. 


\section{Introduction}

It's indispensable to manage an effective working capital for the success and sustainability of the companies. It's important to establish an optimal balance between the assets which constitute working capital in terms of risk, liquidity and profitability of the companies. Time which is spent by the finance managers for the management of working capital components is much more than the time which is spent by them for other financial issues. Importance of working capital arises out of the establishment of the optimal balance between the assets which will enable the sustainability of the company operations, instead of time which is spent by financial managers.

Optimal balance of working capital means decreasing the needs of working capital and increasing the potential sales. An efficient working capital management is enabled by increasing the free cash flow that achieves a growth potential of the company as much as possible. This case would increase the value of the company and also positively affect the income of the shareholders. Traditionally, the recent trend is to increase efficiency in working capital management although finance managers are focused on long-term capital budgets and capital structure decisions (Ganesan, 2007; Lamberson, 1995).

There is no specific application for the efficiency of working capital. It may vary from sector to sector depending on the year. It's impossible to determine the ratio of working capital components within the assets in the same way for each company. It can be an indication for the working capital to differ among the companies when we consider that the sector has its own unique characteristics and economy changes from year to year. Studies also prove this (Filbeck \& Krueger, 2005; Lamberson, 1995; Maxwell et al. 1998).

Previous studies have analysed the working capital elements of the companies in different sectors in the same country. However; the aim of this study is to compare whether these components, which differ depending on sectors and years, also differ in the same sector but in different countries or not. Accordingly, working capital elements of two companies operating in two different countries in cement sector have been analysed. India and Turkey have been chosen as the countries.

In the following section, literature summary will be given and method will be mentioned afterwards. Fourth section will be about findings and the last section will be the conclusion. 


\section{Literature Review}

Academic studies which are carried out on working capital management can be classified under four titles. First of them is the cross-sectoral analysis of working capital components. Second group is the analysis of the effect of working capital policies on the risks and income level of the companies. Third group is the analysis of the effect of working capital management on profitability. And finally, the fourth group is the determination of indicators of working capital. Although all these studies seem identical, they handle different aspects of working capital.

First studies on working capital have indirectly analysed working capital (Gupta, 1969; Gupta \& Huefner, 1972; Gombola \& Ketz, 1983). The common characteristic of these studies is that they put forward the averages of cross-sectoral financial ratios. Consequently; profitability, liquidity and activity ratios of the companies vary depending on the sectors. Studies, which have directly analysed the efficiency of working capital management via financial ratios depending on the sector, have also put forward similar consequences (Filbeck \& Krueger, 2005; Maxwell et al. 1998; Weinraub \& Visscher, 1998; Hawawini et al., 1986). Accordingly, ratios which put forward the efficiency of working capital management also vary depending on the sectors, like the other ratios.

Second group studies have analysed the effect of working capital policies on the risks and income of the companies. In the studies (Gardner et al. 1986; Weinraub \& Visscher, 1998), it has been realized that companies which prefer aggressive working capital policies are profitable but risky while companies which prefer conservative policies have a lower level of income but are less risky. However; Nazir \& Afza (2009) asserts that companies which prefer aggressive working capital lose money, contrary to these studies.

Third group studies have analysed that working capital components increase the profitability of the companies when they are well managed. Shin and Soenen (1998), Deloof (2003), Lazaridis \& Tryfonidis (2006), Ugurlu et al. (2014), Mathuva (2009) and Dursun \& Ayrıçay (2012) suggest that there is a statistically significant relationship between working capital management and profitability. In accordance with these studies, managers should sell off their inventories and collect their receivables as soon as possible if they want to increase their profitability. 
Fourth group studies have analyzed the indicators of the requirement of working capital. Factors which affect the requirement of working capital have been determined as company size (Nazir \& Afza, 2009; Mansoori \& Muhammad, 2012; Akinlo, 2012), financial leverage (Öztürk \& Demirgüneş, 2008; Chiou et al., 2006; Akinlo, 2012; Vijayalakshmi \& Bansal, 2013) and return on assets (Öztürk \& Demirgüneş, 2008; Ugurlu et al., 2014; Abbadi \& Abbadi, 2013; Archavli, et al., 2012; Doğan \& Elitaş, 2014).

\section{Methodology}

\subsection{Data}

The secondary data was gathered from the Thomson Reuters Eikon application. The sample consists of 39 Indian and 20 Turkish firms. There are 45 cement firms listed at Bombay Stock Exchange out of which 39 are selected. All the Turkish cement firms listed at Borsa Istanbul are selected. The firms those were not included in the sample because of missing data. The study covered a period of eight years from 2007 to 2014. The data was examined with the help of working capital financial ratios, statistical tools like mean, max, min, Standard deviation, t-stats and $\mathrm{P}$ values. As a statistic packaged software, Stata 13 was used. In order to analyze the hypothesis, t-test statistics is performed.

\subsection{Variables}

In this study, the variables AVID, AVPD, AVNTC, AVRCD, CE/ASSET, and WC/SALE are used to analyse the working capital and its various components. ROA, ROE, and NPM are used the financial performance of profitability.

Average Number of Days Inventories (AVID) is calculated as (inventories x 365)/ cost of goods sold.

Average Number of Days Accounts Payable (AVPD) is calculated as (accounts payable $\mathrm{x}$ $365) /$ cost of goods sold.

Average Number of Days Accounts Receivable (AVRCD) is calculated as (accounts receivable $\mathrm{x} 365) /$ sales.

Average Net Trade Cycle (AVNTC) is calculated as (number of days accounts receivable + number of days inventory - the number of days accounts payable). 
Cash and Equivalents / Total Asset (CE/ASSET) is calculated as Cash and Equivalent is divided into the total asset.

Working Capital / Sales (WC/SALE) is calculated as (current assets - current liabilities)/ Sale.

Return on Assets (ROA) is calculated as Net Income / Total Assets.

Return on Equity (ROE) is calculated as Net Income / Equity.

Net Profit Margin (NPM) is calculated as Net Profit / Total Sale.

Table 1

Definition of Variables Used in the Sample

\begin{tabular}{ll}
\hline Variables & Explanation \\
\hline AVID & (inventories x 365)/ cost of goods sold \\
AVPD & (accounts payable x 365)/ cost of goods sold. \\
AVRCD & (accounts receivable x 365)/sales \\
AVNTC & (number of days accounts receivable + number of days \\
CE/ASSET & cash and equivalents / total asset \\
WC/SALE & (current assets - current liabilities)/ Sale \\
ROA & Net Income / Total Assets \\
ROE & Net Income / Equity \\
NPM & Net Profit / Total Sale \\
\hline
\end{tabular}

\subsection{Hypotheses}

The hypotheses of this study are:

$\mathrm{H}_{0}$ : There is no significant difference between Indian and Turkish cement firms in terms of AVID, AVPD, AVNTC, AVRCD, CE/ASSET, WC/SALE, ROA, ROE, NPM.

$\mathrm{H}_{1}$ : There is a significant difference between Indian and Turkish cement firms in terms of AVID, AVPD, AVNTC, AVRCD, CE/ASSET, WC/SALE, ROA, ROE, NPM.

\section{Findings}

In order to find out significant differences between Indian and Turkish cement firms, the independent t-test is conducted. Before the t-test, descriptive statistics-mean, minimum, maximum and std. dev. values- have been calculated. Table 2 and Table 3 show the descriptive 
statistics of 39 Indian and 20 Turkish cement firms, respectively for eight years from a period of 2007-2014.

Table 2

Descriptive Statistics of 39 Indian Cement Firms

\begin{tabular}{lccccc}
\hline Variables & Observation & Mean & Minimum & Maximum & Std. Dev. \\
\hline AVID & 284 & 112.0845 & 22 & 454 & 64.10608 \\
AVPD & 277 & 74.41439 & .0343342 & 609.2029 & 75.41877 \\
AVNTC & 288 & 116.5504 & -116.4384 & 826.3374 & 108.3742 \\
AVRCD & 281 & 63.43499 & 8.553421 & 492.9876 & 57.22029 \\
CE/ASSET \%) & 118 & 4.785434 & .0375443 & 21.29018 & 5.361839 \\
WC/SALE (\%) & 282 & 13.4634 & -71.53766 & 209.2199 & 27.66687 \\
ROA (\%) & 286 & 6.464879 & -16.44549 & 41.32822 & 8.047838 \\
ROE (\%) & 283 & 13.49683 & -129.1125 & 84.93152 & 22.38286 \\
NPM (\%) & 316 & 6.861916 & -55.57609 & 51.58024 & 10.4249 \\
\hline
\end{tabular}

Table 3

Descriptive Statistics of 20 Turkish Cement Firms

\begin{tabular}{lccccc}
\hline Variables & Observation & Mean & Minimum & Maximum & Std. Dev. \\
\hline AVID & 180 & 86.2611 & 2 & 276 & 48.676 \\
AVPD & 180 & 50.2102 & 18.0717 & 609.2029 & 126.8382 \\
AVNTC & 180 & 128.3618 & 3.5523 & 341.1202 & 69.5678 \\
AVRCD & 180 & 92.2799 & 25.6128 & 239.5427 & 35.73956 \\
CE/ASSET \%) & 164 & 8.03467 & 0.00076 & 41.6333 & 9.8247 \\
WC/SALE (\%) & 180 & 32.8903 & -20.17882 & 93.8406 & 24.0260 \\
ROA (\%) & 180 & 8.3172 & -20.2018 & 39.27427 & 10.03259 \\
ROE (\%) & 180 & 10.22327 & -72.29281 & 44.12517 & 15.4479 \\
NPM (\%) & 180 & 11.68756 & -22.34932 & 60.5487 & 14.1552 \\
\hline
\end{tabular}

Table 4 shows the basic indicators of working capital components and profitability of Indian and Turkish cement firms from 2007 to 2014. This table also shows the t-test statistics that 
test the hypotheses whether there are significant differences in terms of variables between Indian and Turkish cement firms.

Table 4

t-test for comparison of means between Indian and Turkish Cement Firms

\begin{tabular}{|c|c|c|c|c|c|c|}
\hline Variable & Nationality & Observation & Mean & t-stat & Df & $\mathbf{P}$ \\
\hline \multirow[t]{2}{*}{ AVID } & Indian & 284 & 112.0845 & 4.6245 & 462 & 0.0000 \\
\hline & Turkish & 180 & 86.26111 & & & \\
\hline \multirow[t]{2}{*}{ AVPD } & Indian & 277 & 74.41439 & 4.2053 & 455 & 0.0000 \\
\hline & Turkish & 180 & 50.21023 & & & \\
\hline \multirow[t]{2}{*}{ AVNTC } & Indian & 288 & 116.5504 & -1.3037 & 466 & 0.1930 \\
\hline & Turkish & 180 & 128.3618 & & & \\
\hline \multirow[t]{2}{*}{ AVRCD } & Indian & 281 & 63.43499 & -6.0483 & 459 & 0.0000 \\
\hline & Turkish & 180 & 92.27996 & & & \\
\hline \multirow[t]{2}{*}{ CE/ASSET } & Indian & 118 & 4.785434 & -3.2592 & 280 & 0.0013 \\
\hline & Turkish & 164 & 8.034678 & & & \\
\hline \multirow[t]{2}{*}{ WC/SALE } & Indian & 282 & 13.4634 & -7.7397 & 460 & 0.0000 \\
\hline & Turkish & 180 & 32.89033 & & & \\
\hline \multirow[t]{2}{*}{ ROA } & Indian & 286 & 6.464879 & -2.1959 & 464 & 0.0286 \\
\hline & Turkish & 180 & 8.317283 & & & \\
\hline \multirow[t]{2}{*}{ ROE } & Indian & 283 & 13.49683 & 1.7187 & 461 & 0.0863 \\
\hline & Turkish & 180 & 10.22327 & & & \\
\hline \multirow[t]{2}{*}{ NPM } & Indian & 316 & 6.861916 & -4.3381 & 494 & 0.0000 \\
\hline & Turkish & 180 & 11.68756 & & & \\
\hline
\end{tabular}

On average, Turkish firms have shorter days inventory outstanding than Indian ones (AVID $=112.08$ and 86.26, for Indian and Turkish ones respectively). Average Number of Days Inventories (AVID) measures how fast a firm is converting its entire inventory into a sale. A short number of days mean that a company is more efficient at selling off its inventory.

The Average Number of Days Accounts Payable (AVPD) ratio of Indian Firms is higher than Turkish ones $(\mathrm{AVPD}=74.41$ and 50.21, for Indian and Turkish ones respectively). The average days payable ratio shows the average number of days it takes for a company to pay its 
suppliers or creditors. A higher AVPD is better for a company because it can use its cash for other aims.

The Average Number of Days Accounts Receivable (AVRCD) ratio of Indian firms is shorter than Turkish ones (AVRCD= 63.43 and 92.28, for Indian and Turkish ones respectively). The average number of days accounts receivable ratio measures the number of days that a company takes to collect payments after a sale. A low AVRCD means that a company does not have collection problems of its accounts receivable. It also shows the effectiveness of a company's credit and collection efforts.

The mean of cash and an equivalent asset to total asset (CE/ASSET) ratio of Indian firms is lower than Turkish ones (CE/ASSET $=4.79 \%$ and $8.03 \%$, for Indian and Turkish ones respectively). In the balance sheet, the most liquid assets are cash and equivalents. These assets are cash or can be converted to the cash rapidly. This ratio measures cash and equivalents as a percentage of total assets.

The mean of working capital to sale (WC/SALE) ratio of Indian firms is lower than Turkish ones (WC/SALE $=13.46 \%$ and $32.89 \%$, for Indian and Turkish ones respectively). This ratio shows a company's ability to finance additional sales without getting extra debt. The higher the ratio, the more cash, and equivalents the company has available to meet the short-term needs.

On average, Turkish firms have higher profitability than Indian ones ( $\mathrm{ROA}=6.46 \%$ and $8.32 \%$, for Indian and Turkish ones respectively). As for NPM, there is a consistent result. Turkish firms' average net profit margin is $11.69 \%$, and Indian firms' is $6.86 \%$. However, Indian firms' the average return on equity (ROE) is higher than Turkish ones. There is a significant difference between them, but the significance level is at $10 \%$.

As can be seen in Table 4 only the mean of AVNTC is not statistically different. In other words, there is no significant difference between Indian and Turkish cement firms in terms of AVNTC. However, in all variables except ROE, there are significant differences at the 1 and 5 percent level. ROE is significant at the 10 percent level.

As a result, $\mathrm{H}_{0}$ is rejected. We can conclude that there is a significant difference between Indian and Turkish cement firms in terms of working capital components and profitability ratios. 


\section{Conclusion}

Working capital management has an important place in the decisions of financial management of the company. The aim of working capital is to establish an optimal balance between the elements which constitute working capital. The financial success of the company will be enabled through the increase in the company value. One of the most important issues which increase company value is an efficient and profitable working capital management. Company success is closely related with the efficient management of accounts receivable, inventories and accounts payable which are the components of working capital.

In this study; working capital elements of 39 Indian companies listed in Bombay Stock Exchange and 20 Turkish companies listed in İstanbul Stock Exchange all of which have operated on stones and soil between (cement industry) 2007 and 2014 have been compared. In accordance with the results, Turkish companies convert their inventories into cash much more quickly than Indian companies. It can be said that Turkish companies have a more efficient management mentality in the management of inventories. However; in the collection of receivables, Indian companies have a much more efficient management mentality than Turkish companies. Indian companies collect their receivables in a shorter time period than Turkish companies.

Furthermore; Turkish companies pay their accounts payable in a shorter time than Indian companies. Indian companies pay their accounts payable in a longer period on average, but they can evaluate these funds in the meantime. So, they follow a more efficient policy than Turkish companies in terms of debt management.

When we consider that Turkish companies have much more cash and equivalent assets within their total assets on average than Indian companies, it shows that Turkish companies attribute much more importance to liquidity. It enables flexibility to Turkish companies in case of any negative cases to make their short-term debt payments.

It has been determined that the ratios of working capital to sales are higher in Turkish companies than Indian companies on average. As indicated above, it is clear that Turkish companies attribute much more importance to liquidity. Highness of this rate on average indicates that Turkish companies would not need to find additional accounts payable for additional sales. On the other hand, Indian companies decrease their financing costs by not 
investing in working capital much. The additional fund which is invested in working capital causes that the company cannot derive benefit from alternative investment opportunities. Indian companies would increase the amounts of funds which they can use for growing by decreasing this kind of funds.

Return on Assets and net profit margin of Turkish companies are much more than Indian companies on average. Return on equity of Indian companies is much more than Turkish companies on average. However; this study does not analyse whether the profitability of the companies arises out of working capital or not. A different analysis is necessary for this. In this study, the average differences between the profitability of the companies from only two countries have been analysed.

Consequently; there are no different results in this study although there have been different results regarding these elements in the previous studies which have analysed the working capital elements of the companies. In other words; working capital components of the companies are statistically different from each other. However; this study is different from the others in that: companies which operate in the same country but different sectors have been handled in the other studies while companies in the same sector but two different countries have been handled in this study. 


\section{References}

Abbadi, S. M. \& Abbadi, R. T. (2012). The determinants of working capital requirements in Palestinian industrial corporations. International Journal of Economics and Finance, 5(1), $65-75$.

Akinlo, O. O. (2012). Determinants of working capital requirements in selected quoted companies in Nigeria. Journal of African Business, 13(1), 40-50.

Archavli, E., Siriopoulos, C. \& Arvanitis, S. (2012). Determinants of working capital management. Retrieved from http://www.teicrete.gr/mscaccaud/resources/Conferences/ICESAL/2012/ICESAL-12_Archavli_etal abstract.pdf Available at SSRN 2179907.

Chiou, J. R., Cheng, L. \& Wu, H. W. (2006). The determinants of working capital management. Journal of American Academy of Business, 10(1), 149-155.

Deloof, M. (2003). Does working capital management affect the profitability of Belgian firms?. Journal of business finance \& Accounting, 30(3-4), 573-588.

Doğan, M. \& Elitaş, B. L. (2014). Çalişma sermayesi gereksiniminin belirleyicileri: Borsa İstanbul gida sektörü üzerine bir inceleme. World of Accounting Science, 16(2), 1-14.

Dursun, A. \& Ayrıçay, Y. (2012). Çalişma sermayesi-kârlilik ilişkisinin İmkb örneğinde 19962005 dönemi analizi. Atatürk Üniversitesi İktisadi ve İdari Bilimler Dergisi, 26(3-4), 199214.

Filbeck, G. \& Krueger, T. M. (2005). An analysis of working capital management results across industries. American Journal of Business, 20(2), 11-20.

Ganesan, V. (2007). An analysis of working capital management efficiency in telecommunication equipment industry. Rivier academic journal, 3(2), 1-10.

Gardner, M. J., Mills, D. L. \& Pope, R. A. (1986). Working capital policy and operating risk: An empirical analysis. Financial Review, 21(3), 31-31.

Gombola, M. J. \& Ketz, J. E. (1983). Financial ratio patterns in retail and manufacturing organizations. Financial Management, 12(2), 45-56.

Gupta, M. C. (1969). The effect of size, growth, and industry on the financial structure of manufacturing companies. The Journal of Finance, 24(3), 517-529.

Gupta, M. C. \& Huefner, R. J. (1972). A cluster analysis study of financial ratios and industry characteristics. Journal of Accounting Research, 10(1), 77-95.

Hawawini, G., Viallet, C. \& Vora, A. (1986). Industry influence on corporate working capital decisions. MPRA Paper No. 44894, Retreived from https://core.ac.uk/download/pdf/12035746.pdf

Lamberson, M. (1995). Changes in working capital of small firms in relation to changes in economic activity. American Journal of Business, 10(2), 45-50.

Lazaridis, I. \& Tryfonidis, D. (2006). Relationship between working capital management and profitability of listed companies in the Athens stock exchange. Journal of Financial Management and Analysis, 19(1), 26-35. 
Mansoori, D. E. \& Muhammad, D. J. (2012). Determinants of working capital management: Case of Singapore firms. Research Journal of Finance and Accounting, 3(11), 15-23.

Mathuva, D. (2009). The influence of working capital management components on corporate profitability: A survey on Kenyan listed firms. Research Journal of Business Management, 3(1), 1-11.

Maxwell, C. E., Gitman, L. J. \& Smith, S. A. (1998). Working capital management and financialservice consumption preferences of US and foreign firms: A comparison of 1979 and 1996 preferences. Financial Practice and Education, 8, 46-52.

Nazir, M. S. \& Afza, T. (2009). Impact of aggressive working capital management policy on firms' profitability. The IUP journal of applied finance,15(8), 19-30.

Öztürk, M. B. \& Demirgüneş, K. (2008). İşletme sermayesi gereksinimini etkileyen değişkenler üzerine İMKB'de bir uygulama. Finans Politik \& Ekonomik Yorumlar, 45(516), 47-56.

Shin, H. H. \& Soenen, L. (1998). Efficiency of working capital management and corporate profitability. Financial practice and education, 8, 37-45.

Ugurlu, E., Jindrichovska, I. \& Kubickova, D. (2014). Working capital management in czech smes: An econometric approach. ICESBA, 23-24 Bucharest Romania.

Vijayalakshmi, S. \& Bansal, N. (2013). Determinants of working capital in cement industry-a case study of ACC Ltd. Pacific Business Review International, 6(1), 45-50.

Weinraub, H. J. \& Visscher, S. (1998). Industry practice relating to aggressive conservative working capital policies. Journal of Financial and Strategic Decision, 11(2), 11-18. 